\title{
Genetic diversity of Pleurotus ostreatus (Jacq.) P. Kumm. strains in Java based on random amplified polymorphic DNA markers
}

\author{
NURAENI EKOWATI ${ }^{1, \bullet}$, ARIS MUMPUNI ${ }^{1}$, JUNI SAFITRI MULJOWATI ${ }^{1}$, NUNIEK INA RATNANINGTYAS ${ }^{1}$, \\ ARDHINI RIN MAHARNING ${ }^{2}$ \\ ${ }^{1}$ Mycology Laboratory, Faculty of Biology, Universitas Jenderal Soedirman. J1. Dr. Soeparno 63, Purwokerto, Banyumas 53122, Central Java, Indonesia \\ ${ }^{2}$ Ecology Laboratory Faculty of Biology. Universitas Jenderal Soedirman. J1. Dr. Soeparno 63, Purwokerto, Banyumas 53122, Central Java, Indonesia. \\ Tel.: +62-281-638794, Fax.: +62-281-631700, `email: nuraeniekowati29@gmail.com
}

Manuscript received: 30 September 2020. Revision accepted: 30 May 2021.

\begin{abstract}
Ekowati N, Mumpuni A, Muljowati JS, Ratnaningtyas NI, Maharning AR. 2021. Genetic diversity of Pleurotus ostreatus (Jacq.) P. Kumm. strains in Java based on Random Amplified Polymorphic DNA markers. Biodiversitas 22: 3488-3493. Genetic variation in a fungal population can occur due to mutation and recombination, resulting in changes in the nucleotides that encode specific DNA sequences. Strains with a high genetic distance and good production capabilities can be used to develop genetic breeding. This study aimed to investigate genetic relationship among Pleurotus ostreatus strains cultivated in Java (Bogor, Cianjur, Tasikmalaya, Purwokerto, Yogyakarta, Tawangmangu, Malang, and Madiun) based on random amplified polymorphic DNA (RAPD) markers. The research method consisted of DNA isolation and DNA amplification using six primers, i.e. OPA2, OPA3, OPA4, OPA7, OPA9, and OPA10. DNA band data were analyzed using NTSYSpc21 software to determine the level of genetic similarity, based on the Unweighted Pair Group Method with Arithmetic Average Algorithm (UPGMA). In all, 101 amplified DNA bands were obtained, with sizes ranging from 136 to $2320 \mathrm{bp}$ and $96.0 \%$ of the bands were polymorphic. Based on cluster analysis, it shows that three clusters were formed. There were genetic variations and relationships among eight $P$. ostreatus strains in Java with a genetic similarity varying from $37-98 \%$.
\end{abstract}

Keywords: Genetic diversity, Pleurotus ostreatus, polymorphism, primers, RAPD

\section{INTRODUCTION}

Pleurotus ostreatus (Jacq.) P. Kumm. is a type of edible mushroom with high nutritive value and cultivated in several regions in Indonesia. This fungus is known as a white oyster mushroom because of its white color and shape cap. It can be grown on various agricultural wastes as media (Tsegaye and Tefera 2018). Among P. ostreatus cultivation centers in Indonesia, particularly Java including Bogor, Cianjur, Tasikmalaya, Purwokerto, Yogyakarta, Tawangmangu, Malang, and Madiun, it is suspected that cultivation of the fungus has resulted in several strains representing some genetic diversity. $P$. ostreatus has good nutritional value, resulting in increased interest in its cultivation. The determination of genotypic identity is also important for analyses of populations, structure, and evolution within and among species. An important issue is the identification of species beyond morphological and physiological criteria, as this affects fruiting bodies (Khan et al. 2011). This mushroom has low resource and space requirements and can be grown throughout the world and year-round from low-cost starting materials (Chakravarty 2011).

Information regarding genetic variation in $P$. ostreatus strains cultivated in Java is particularly important for selecting superior strains for further development. Inyod et al. (2017) reported that traditional morphological characterization must be supplemented with molecular characterization to obtain more accurate results. Gupta et al. (2011) and Hasan et al. (2018) reported the development of molecular techniques that can genetically differentiate individuals from one another, in addition to fungal populations. Knowing genetic diversity in P. ostreatus will assist in the process of selecting parent strains (parental selection) that are genetically superior. One technique that can be used to determine genetic diversity is the random amplified polymorphic DNA (RAPD) technique. This method can be used to analyze whether there are significant genetic differences in isolates from different locations.

The RAPD technique can easily and quickly detect genetic changes throughout the genome and can be performed with small amounts of DNA. Therefore RAPDPCR is becoming an extremely popular technique. It has numerous applications such as genetic mapping for fungi, DNA fingerprinting, population genetics studies, epidemiological studies, and the identification of fungal strains (Abdulmalk 2013). Genotyping is particularly important in analyses of population biology, involving the construction of genetic maps and recognizing evolutionary changes. Genetic variation can occur due to changes in the nucleotides that make up an organism's DNA molecules. These changes can in turn then affect phenotypes or reactions to a particular environment. Strains with a high genetic distance and good production ability can be used in genetic breeding (Khan et al. 2011). 
The genetic diversity analysis on mushrooms has been using RAPD marker. This technique can determine the genetic similarity of Pleurotus strains (Ravash et al. 2010 and Khan et al. 2017). Analysis of the genetic diversity of Pleurotus have been conducted on wild or cultivated individual and showed high genetic diversity (Otieno and Onyango 2015). Khan et al. (2017) reported that genetic diversity on local and exotic of $P$. ostreatus using RAPD markers produced 70 bands that could be scored, of which 41 bands were polymorphic, with an average of 2.73 polymorphic bands per primer.

The $P$. ostreatus strains used in this study were commercially cultivated. However, to date, no studies have quantified the genetic diversity of isolates from these various cultivation centers. This study aimed to investigate genetic relationship among $P$. ostreatus strains cultivated in Java (Bogor, Cianjur, Tasikmalaya, Purwokerto, Yogyakarta, Tawangmangu, Malang, and Madiun) based on RAPD markers.

\section{MATERIALS AND METHODS}

\section{Research materials}

The study was conducted using a survey method, taking two samples of $P$. ostreatus mushrooms from each location. Eight strains were analyzed, one each originating from Bogor (PoB), Cianjur (PoC), Tasikmalaya (PoTs), Purwokerto (PoP), Yogyakarta (PoY), Tawangmangu (PoTw), Malang (PoMl), and Madiun (PoMd). All fungal strains were obtained in the form of pure mycelium culture. Then molecular research was done in Mycology Laboratory, Faculty of Biology, University of Jenderal Soedirman, Purwokerto Indonesia.

\section{DNA extraction}

The eight fungal strains were cultured on $50 \mathrm{~mL}$ potato dextrose broth (PDB) and incubated in a rotary shaker at $28^{\circ} \mathrm{C}$ for 15 days at a speed of $100 \mathrm{rpm}$. Mycelia were harvested using Whatman filter paper no. 41 in a Büchner funnel and used for DNA isolation (Ekowati et al. 2011).

The Nucleon Phytopure fungal DNA extraction RPN8511/GE (Healthcare, UK) Kit was used to accomplish genomic DNA isolation. Fresh mycelia from $0.1 \mathrm{~g}$ to $0.3 \mathrm{~g}$ were crushed in liquid nitrogen and placed into $1.5 \mathrm{~mL}$ Eppendorf tubes. Then, $500 \mu \mathrm{L}$ Phytopure I Reagent was added, and the mixture was homogenized by hand or vortex. Next, $200 \mu \mathrm{L}$ Phytopure II Reagent was added. Samples were incubated at $65^{\circ} \mathrm{C}$ for $10 \mathrm{~min}$ in a water bath, then at $4^{\circ} \mathrm{C}$ for $20 \mathrm{~min}$. Next, $400 \mu \mathrm{L}$ cold chloroform that had been stored at $4^{\circ} \mathrm{C}$ was added to the samples and $20 \mu \mathrm{L}$ Phytopure III reagent (resin) was added. Centrifugation was performed using a microcentrifuge at a speed of 1,300 $\times \mathrm{g}$ for $15 \mathrm{~min}$ at RT until the upper phase in each sample was clear. The supernatant portions containing DNA in a 200 to $250 \mu \mathrm{L}$ volume were transferred to new $1.5 \mathrm{~mL}$ tubes. Cold isopropanol/propanol with a volume equal to that of the supernatant was added. Then the tubes were closed and inverted to combine the supernatant and isopropanol. Centrifugation was performed at $4,000 \times \mathrm{g}$ for
$5 \mathrm{~min}$ at room temperature. The supernatants were discarded and the precipitates (pellets) were washed by adding $100 \mu \mathrm{L} 70 \%$ ethanol. Then the samples were centrifuged three times at $4,000 \times \mathrm{g}$ for $5 \mathrm{~min}$, and after each centrifugation, any remaining ethanol was removed by opening and inverting the tubes on tissue paper until the sediments (pellets) were dry. After drying, the pellets were each resuspended in $100 \mu \mathrm{L}$ Tris-EDTA (TE) buffer. These aqueous DNA samples were stored at $-20^{\circ} \mathrm{C}$ until further analyses. To assess the quality of genomic DNA extracted from each $P$. ostreatus strain, the samples were electrophoresed before RAPD analyses.

\section{PCR reaction and electrophoresis}

DNA amplification was performed with the PCRRAPD technique, using six primers 10 nucleotides in length, i.e. OPA2, OPA3, OPA4, OPA7, OPA9, and OPA10. Each sample was prepared for PCR with the following reaction components: $13.0 \mu \mathrm{L}$ kit Master mix (dNTP, Taq-DNA polymerase, $1 \mathrm{X}$ magnesium chloride buffer $), 2.5 \mu \mathrm{L}$ primer $(30.0 \mathrm{pmol})$, and $3.0 \mu \mathrm{L}$ the appropriate DNA sample $(50.0 \mathrm{ng} / \mathrm{mL})$. Nuclease-free water was added to a $25 \mu \mathrm{L}$ total volume for each sample. The samples were placed in a thermocycler programmed as follows: one initial stage of denaturation at $92^{\circ} \mathrm{C}$ for $3 \mathrm{~min}$, then a set of 45 cycles were carried out. Each cycle consisted of temperature settings of $92^{\circ} \mathrm{C}$ for $1 \mathrm{~min}$ to denature the DNA, $37^{\circ} \mathrm{C}$ for $1 \mathrm{~min}$ to anneal primers to template, and $72^{\circ} \mathrm{C}$ for $2 \mathrm{~min}$ for extension. After 45 cycles, extension at $72^{\circ} \mathrm{C}$ was carried out for $10 \mathrm{~min}$. Then the samples were cooled to $4^{\circ} \mathrm{C}$. The amplified samples were removed from the thermocycler and stored at $-20^{\circ} \mathrm{C}$ for later gel electrophoresis analyses. Each reaction was repeated three times.

Amplified DNA samples were electrophoresed using $2 \%$ agarose gel in Tris-Borat-EDTA $1 \mathrm{X}$ (TBE). The gels were immersed in a $1 \mathrm{X}$ TBE running buffer. A total of 5 $\mu \mathrm{L}$ of each amplified sample was mixed with $1 \mu \mathrm{L}$ loading dye, pipetted into a separate well in the gel, and then exposed to a $100 \mathrm{~V}$ field for $30 \mathrm{~min}$. Then the gels were immersed in ethidium bromide (EtBr) for $30 \mathrm{~min}$. DNA bands were visualized with a UV transilluminator (Khan et al. 2017; Familoni et al. 2018).

\section{Data analysis}

The amplified DNA band data were analyzed for size and assessed based on the appearance of the bands. The data obtained were analyzed using the Numerical Taxonomy and Multivariate Analysis System Program, Version 2.1. (NTSYSpc21). Genetic similarity among accessions was calculated according to Jaccard's similarity coefficients using SIMQUAL (Similarity for Qualitative Data). The similarity coefficients were then used to construct dendrogram based on the unweighted pair group method with arithmetic average algorithm (UPGMA) (Rohlf 2000). 


\section{RESULTS AND DISCUSSION}

\section{RAPD profiles}

DNA was isolated at concentrations between 210.20$2152.90 \mu \mathrm{g} / \mathrm{mL}$ with a DNA/RNA ratio between 1.86 and 2.10. The samples were of good quality, quantity, and purity (Figure 1). Template DNA purity is important for its use in PCR amplification. According to Sharon (2010), DNA isolation results are ideal if the ratio of DNA to RNA is between 1.8-2. Therefore, the samples possessed sufficient quality for further PCR analyses.

Genomic DNA samples were used for DNA amplification using six primers resulted in different amounts and sizes of amplified DNA band fragments. The results band sizes ranged from 136 to 2,320 base pairs (bp) (Figure 2). Our results are in line with previous studies, which have reported ranges of 200-2,000 bp in $P$. nebrodensis (Alam et al. 2009), 250-3,500 bp in P. eryngii (Ravash et al. 2010), and 646-779 bp in P. sajor-caju (Avin et al. 2013).

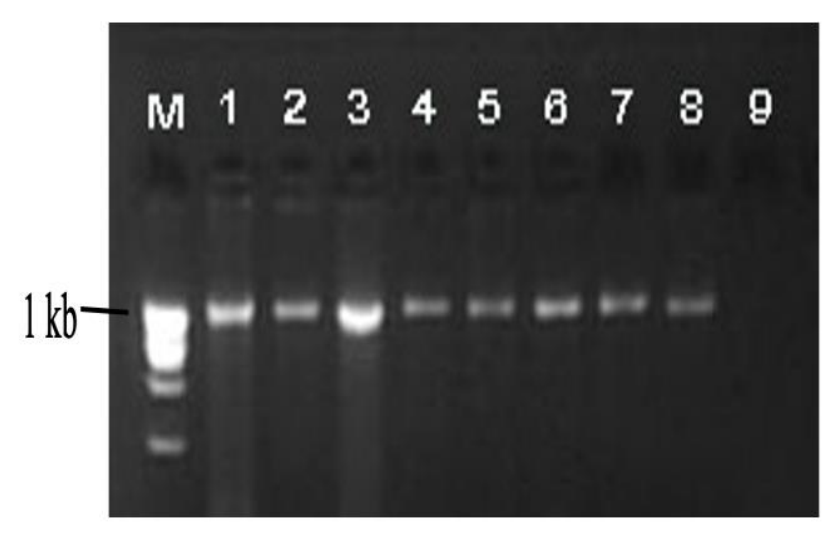

Figure 1. Genomic DNA band isolated from eight Pleurotus ostreatus strains. M: DNA marker $1 \mathrm{~kb}$. Strains 1: Bogor, 2: Cianjur, 3: Tasikmalaya, 4: Purwokerto, 5: Yogyakarta, 6: Tawangmangu, 7: Malang, 8: Madiun, 9: Negative control (without DNA).

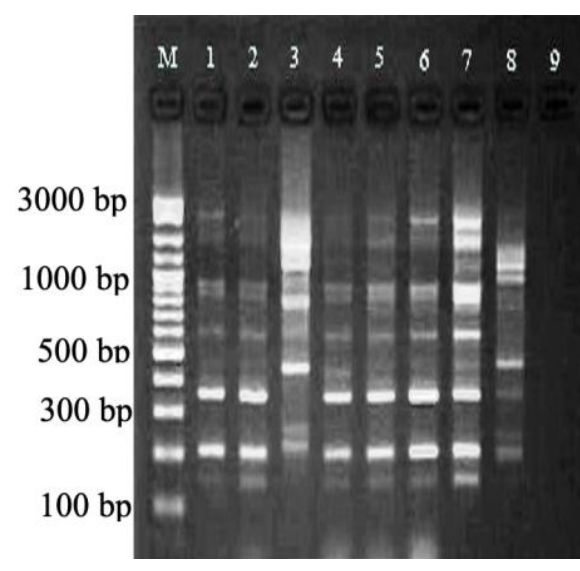

OPA 2

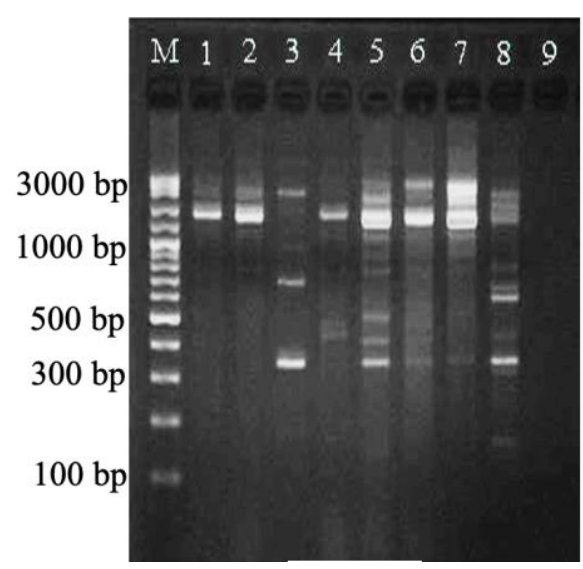

OPA 7

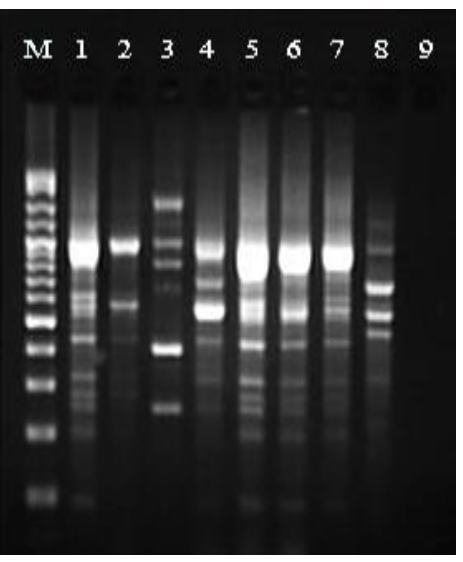

OPA 3

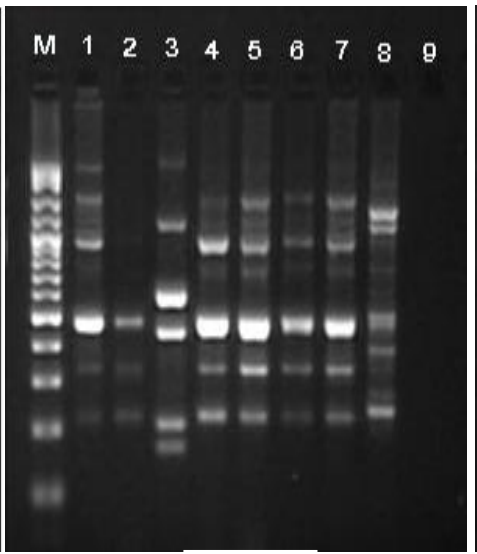

OPA 9

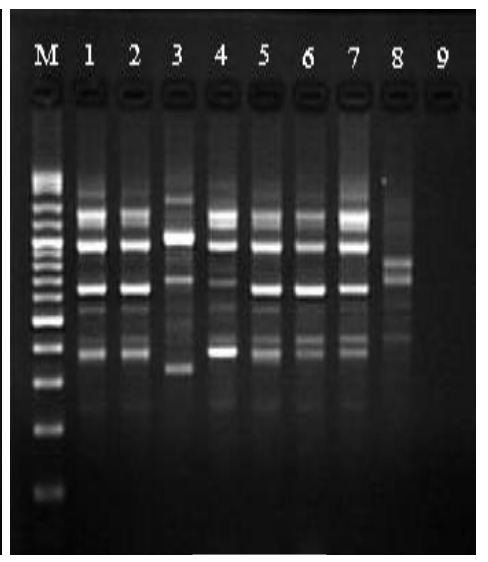

OPA 4

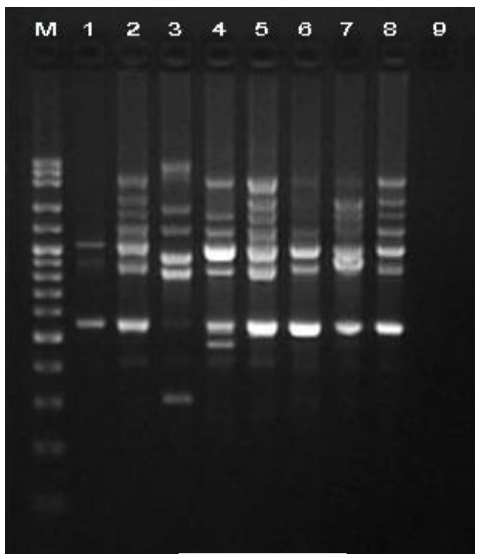

OPA 10

Figure 2. Pattern Pleurotus ostreatus DNA bands amplified using OPA2, OPA3, OPA4, OPA7, OPA9 and OPA10 primers. Note : M: 100 bp DNA marker of P. ostreatus starins 1: Bogor, 2: Cianjur, 3: Tasikmalaya, 4: Purwokerto, 5: Yogyakarta, 6: Tawangmangu, 7: Malang, 8: Madiun, 9: Negative control (without DNA). 
Table 1. DNA size, numbers of amplified and polymorphic bands of eight Pleurotus ostreatus strains amplified using six RAPD primers

\begin{tabular}{cllccc}
\hline No. & \multicolumn{1}{c}{ Primer } & Sequence (5'-3') & $\begin{array}{c}\text { DNA band size } \\
\text { (bp) }\end{array}$ & $\begin{array}{c}\text { Numbers of amplified } \\
\text { DNA bands }\end{array}$ & $\begin{array}{c}\text { Numbers of polymorphic } \\
\text { DNA bands }\end{array}$ \\
\hline 1 & OPA 2 & TGCCGAGCTG & $136-2098$ & 20 & 17 \\
2 & OPA 3 & AGTCAGCCAC & $170-1640$ & 19 & 18 \\
3 & OPA 4 & AATCGGGCTG & $332-2056$ & 17 & 17 \\
4 & OPA 7 & GAAACGGGTG & $330-2256$ & 15 & 15 \\
5 & OPA 9 & GGGTAACGCC & $155-2288$ & 17 & 17 \\
6 & OPA 10 & GTGATCGCAG & $276-2320$ & 13 & 13 \\
& Total & & & 101 & 97 \\
& Average & & & 16.83 & 16.17 \\
\hline
\end{tabular}

The results of polymorphism analyses indicated different levels of polymorphisms resulting from the use of each primer. Of the six primers, all exhibit the presence of polymorphisms among the eight strains of $P$. ostreatus. Thus, the six primers can be used to distinguish genotypes among these strains. The primer that could produce the most polymorphism patterns was OPA3 of 19 amplified DNA bands, and 18 (94.7\%) were polymorphic. Based on the combined results of those six primers, 101 amplified DNA bands were observed, and $97(96.0 \%)$ of the DNA bands were polymorphic. For each primer, the average yield was 16.83 DNA bands per primer (Table 1). Yadav et al. (2017) reported that $79.5 \%$ of RAPD bands of Pleurotus strains were polymorphic, and Pawlik et al. (2012) reported that 21 strains of Pleurotus obtained $90.4 \%$ polymorphism. The polymorphic band obtained from this current study is higher than those two previous studies which can be caused by the variety of primers used and the higher genetic variation of the strains used in this study.

\section{Cluster analysis}

To determine the genetic relationship of the eight $P$. ostreatus strains, the combined data from the six primers were analyzed based on the clustering method of UPGMA to obtain genetic similarity matrix (Table 2) and construct a dendrogram (Figure 3). Based on cluster analysis, it shows that three clusters were formed, the first cluster (I) being a group consisting of PoY, PoMl, PoTw, PoB, PoC, and PoP. Cluster I was divided into four sub-clusters; namely, the first sub-cluster consisted of PoY, PoMl and PoTw which were grouped with high genetic similarity between 0.960.98. The second sub-cluster consisted of one strain, PoB, the third sub-cluster consisted of one strain, $\mathrm{PoC}$, and the fourth sub-cluster consisted of one strain, PoP. The second cluster consisted of one strain, PoMd, and the third cluster consisted of one strain, PoTs.

The different strains show variation in genetic similarity. However, the similarity of six of those strains was very high due to the number of amplicons and the percentage of polymorphic DNA bands determined by the number of selective nucleotides in the strain. In addition, it can be caused by the ancestor of the same strain so that there is only a slight genetic change at some locations. Khan et al. (2011) examined genetic variation in seven Pleurotus species using the RAPD technique and reported a similarity index of $0.76-0.86$. Chandra et al. (2010) tested eight strains of $P$. ostreatus in India and reported a similarity index between 0.111 and 0.727 . Gupta et al. (2011) performed molecular characterization of Pleurotus spp. using the RAPD technique showed genetic similarity between 0.17-0.95. Vieira et al. (2013) carried out the molecular characterization of $P$. ostreatus in Brazil the reported a genetic similarity of 0.69 . Windarsih et al. (2019) reported genetic similarity for four samples of Gracilaria coronopifolia ranged between 0.45-0.57.

In our study, $P$. ostreatus strains from Yogyakarta, Malang, and Tawangmangu showed very high genetic similarity while strain from Malang and Madiun showed closer genetic similarities as well as strain from Tasikmalaya and Cianjur (Figure 3). Geographically, $P$. ostreatus originating from Malang is closer to the strain from Madiun than to the strain from Yogyakarta. However, the Malang strain showed a closer genetic relationship with the Yogyakarta strain than the Madiun strain. Our UPGMA clustering results show that these genetic similarities are not only influenced by geographic distance but are based on genetic factors and other factors. Al-Tufaili et al. (2019) reported that the genetic convergence or divergence among studied strains may be due to many reasons, such as source of origin, different environmental conditions, and breeding or hybridization for these strains. The variation of cultivated strains depends on mutation and hybridization, range of spread, agricultural processes, domestication, or other factors, such as ecological, geographical, breeding system, and anthropogenic effects. Zhao et al. (2013) reported that the genetic distances among geographical populations of $P$. eryngii var. tuoliensis were positively correlated with geographic distance and longitudinal distances. This indicates that geographic isolation is an important factor for the observed genetic differentiation. Zhao et al. (2016) reported that adaptation to stress and a temporarily heterogeneous environment are two important factors that influence intraspecies genetic diversity of $P$. ferulae in China. Phylogenetic analyses have also shown that genetic variation in Chinese samples is not geographically linked to their origin. These results indicate that gene flow is not hindered by distance. The present study reveals the abundant diversity for $P$. ferulae in China although its habitat was restricted. Samples from China and Italy were separated according to their geographical origins, but they belonged to the same genetic group. 
Table 2. Similarity matrix of eight Pleurotus ostreatus strains obtained through RAPD markers

\begin{tabular}{|c|c|c|c|c|c|c|c|c|}
\hline Strains & PoB & PoC & PoTs & PoP & PoY & PoTw & PoMl & PoMd \\
\hline PoB & 1.00 & & & & & & & \\
\hline $\mathrm{PoC}$ & 0.78 & 1.00 & & & & & & \\
\hline PoTs & 0.48 & 0.48 & 1.00 & & & & & \\
\hline PoP & 0.70 & 0.72 & 0.41 & 1.00 & & & & \\
\hline PoY & 0.78 & 0.76 & 0.37 & 0.74 & 1.00 & & & \\
\hline PoTw & 0.80 & 0.72 & 0.38 & 0.72 & 0.96 & 1.00 & & \\
\hline PoMd & 0.50 & 0.64 & 0.46 & 0.52 & 0.52 & 0.50 & 0.54 & 1.00 \\
\hline
\end{tabular}

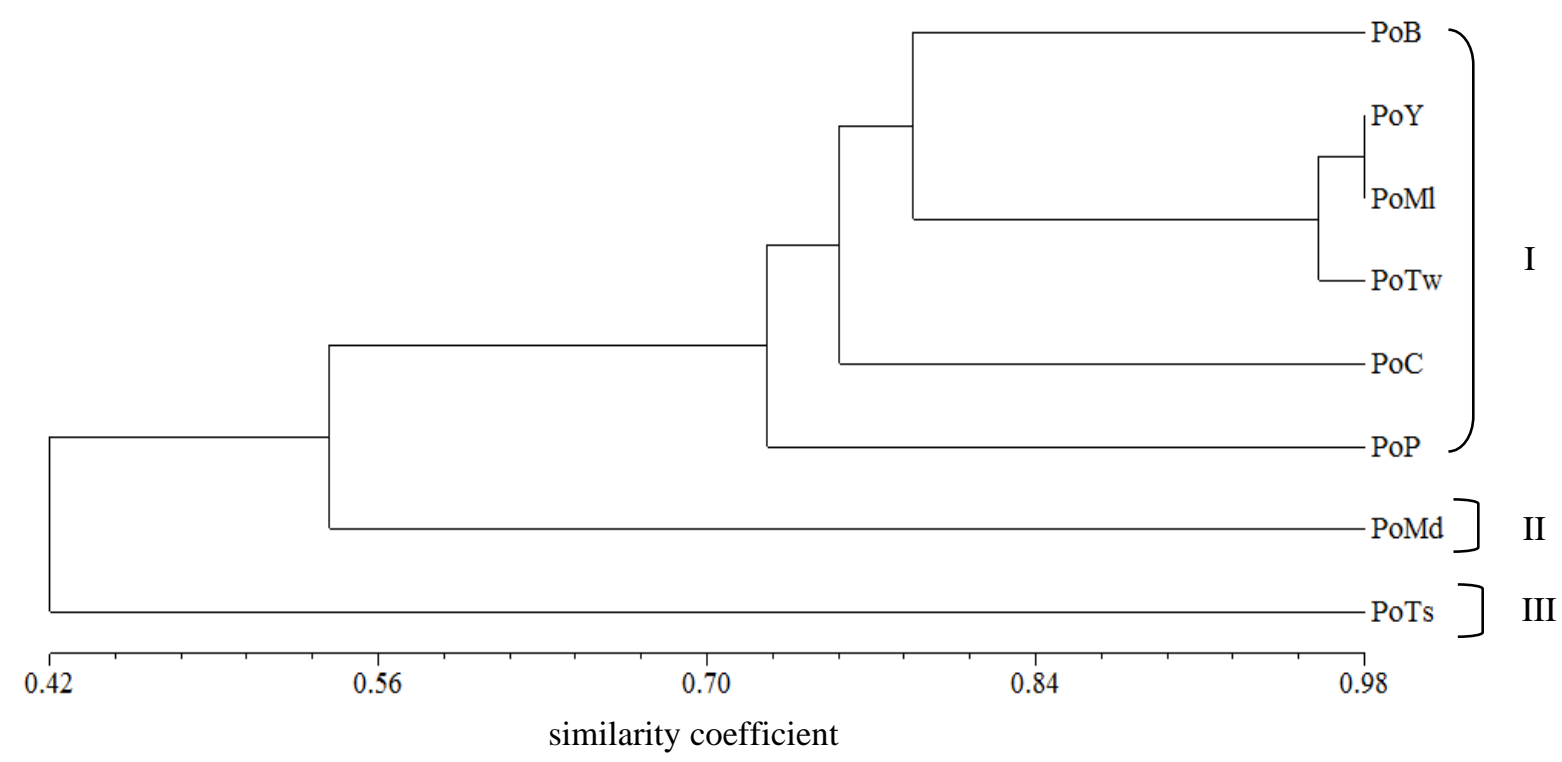

Figure 3. Dendrogram of genetic relationship among the eight strains of Pleurotus ostreatus

$P$. ostreatus strains from Madiun and Tasikmalaya showed quite high genetic differences versus the other six strains, which means that both strains can be used for genetic breeding development. Khan et al. (2011) stated that strains that have a high genetic distance and good production ability can be used in genetic breeding. Barh et al. (2019) reported that the genetic improvement in Pleurotus started with a simple selection technique, which later utilized hybridization (intraspecific, interspecific and intergeneric) and mutation breeding. The traits such as productivity, sporelessness, and quality improvement are important objectives on which most of the works have been done so far. However, new generation approaches such as molecular breeding, genetic transformation and genome editing techniques also added pace to the present improvement process. The improvement of Pleurotus mushroom primarily utilizes selection. Selection may be a direct selection from germplasm collected during fungal forays or from cultures made by multispore germination. Selection and mating of genetically diverse parents is another approach to exploit heterosis through hybridization. Avin et al. (2016) reported that the genetic variance components and heritability analyses indicated that the bulk of the $P$. pulmonarius genetic variations observed for most traits were associated with genes that were dominant in their effects. The newly generated hybrids were identified by both morphological and molecular fingerprinting. Familoni et al. (2018) reported that the outcome of phylogenetic relationships based on the molecular analysis between different or similar populations of Pleurotus species provides a better resolution and understanding of their biogeography and speciation. RAPD is a valuable method in distinguishing the different genotypes in mushrooms and evaluating their genetic similarities

In conclusion, there was variation in the genetic relationship among the eight strains of $P$. ostreatus in Java (Bogor, Cianjur, Tasikmalaya, Purwokerto, Yogyakarta, Tawangmangu, Malang, and Madiun) based on random amplified polymorphic DNA (RAPD) markers, with a genetic similarity varying from $37-98 \%$. Based on cluster analysis, it shows that three clusters were formed.

\section{ACKNOWLEDGEMENTS}

We thank the Ministry of Research Technology and Higher Education for providing research funds through the 
Strategic National Institution Scheme Project. Our gratitude also goes to LPPM Jenderal Soedirman University, Purwokerto, Banyumas, Indonesia for the sharing of information and collaboration; and the Dean of the Faculty of Biology, Jenderal Soedirman University, Purwokerto, for giving the research permission and supporting this research.

\section{REFERENCES}

Abdulmalk HW. 2013. Rapid differentiation of Pleurotus ostreatus from Pleurotus sapidus using PCR technique. Curr Res J Biol Sci 5: 157160. DOI: $10.19026 /$ crjbs.5.5482

Alam N, Shim MJ, Lee MW, Shin PG, Yoo YB, Lee TS. 2009. Phylogenetic relationship in different commercial strains of Pleurotus nebrodensis Based on ITS sequence and RAPD. Mycobiol 37: 183188. DOI: 10.4489/MYCO.2009.37.3.183

Al-Tufaili AKH, Aboohanah MA, Salman FA, Abdel-Hassan NM. 2019 Analysis of genetic distance and similarity in some radish cultivars (Raphanus sativus L.) by random amplified polymorphic DNA (RAPD) markers. J Glob Pharm Technol 11: 464-470.

Avin FA, Bhassu S, Sabaratnam V. 2013. A simple and low-cost technique of DNA extraction from edible mushrooms examined by molecular phylogenetics. Res Crops 14:897-901.

Avin FA, Bhassu S, Rameeh V, Tan YS, Vikineswary S. 2016. Genetics and hybrid breeding of Pleurotus pulmonarius: Heterosis, heritability and combining ability. Euphytica 209: 85-102. DOI: 10.1007/s10681016-1638-x

Barh A, Sharma VP, Annepu SK, Kamal S, Sharma S, Bhatt P. 2019. Genetic improvement in Pleurotus (oyster mushroom): A review. Biotech 9: 322. DOI: 10.1007/s13205-019-1854-x

Chakravarty B. 2011. Trends in mushroom cultivation and breeding. Aus J Agric Eng 2: 102-109.

Chandra S, Ghosh K, Acharya K. 2010. Comparative studies on the Indian cultivated Pleurotus species by RAPD fingerprinting. Nat Sci 8: 90 94.

Ekowati N, Kasiamdari RS, Pusposendjojo N, Soegihardjo CJ. 2011. Genetic variation base on random amplified polymorphic DNA molecular markers on shiitake mushrooms (Lentinula edodes). Biota 16: 178-186. DOI: 10.24002/biota.v16i2.97

Familoni TV, Ogidi CO, Akinyele BJ, Onifade AK. 2018. Genetic diversity, microbiological study and composition of soil associated with wild Pleurotus ostreatus from different locations in Ondo and Ekiti States, Nigeria. Chem Biol Technol Agric 5: 7. DOI: 10.1186/s40538-018-0119-y

Gupta B, Reddy PN, Kotasthane AS. 2011. Molecular characterization and mating type analysis of oyster mushroom (Pleurotus spp.) using single basidiospores for strain improvement. World J Microbiol Biotechnol 27: 1-9. DOI: 10.1007/s11274-010-0419-2
Hasan HA, Almomany AM, Hasan S, Al-Abdallat AM. 2018. Assessment of genetic diversity among Pleurotus spp. isolates from Jordan. J Fungi 4: 52. DOI: 10.3390/jof4020052

Inyod T, Sassanarakit S, Payapanon A, Keawsompong S. 2017. Morphological characteristics and molecular identification of a wild Thai isolate of the tropical mushroom Hed Taen Rad (Macrocybe crassa). Biodiversitas 18: 221-228. DOI: 10.13057/biodiv/d180128

Khan SM, Nawaz A, Malik W, Javed N, Yasmin T, Rehman M, Qayyum A, Iqbal Q, Ahmad T, Khan AA. 2011. Morphological and molecular characterization of Oyster mushroom (Pleurotus spp.). Afr J Biotechnol 10: 2638-2643. DOI: 10.5897/AJB10.499

Khan NA, Binyamin R, Awan FS, Khan AI, Waseem M. 2017. Genetic diversity of edible mushroom Pleurotus spp. revealed by randomly amplified polymorphic DNA fingerprinting. Pak J Bot 49: 1517-1521.

Otieno OD, Onyango C. 2015. Genetic diversity of Kenyan native oyster mushroom (Pleurotus). Mycologia 107: 32-38. DOI: 10.3852/13-186.

Pawlik A, Janusz G, Koszerny J, Małek W, Rogalski J. 2012. Genetic diversity of the edible mushroom Pleurotus sp. by amplified fragment length polymorphism. Curr Microbiol 65: 438-445. DOI: 10.1007/s00284-012-0175-7

Ravash R, Shiran B, Alavi A, Bayat F, Rajaee S, Zervakis GI. 2010. Genetic variability and molecular phylogeny of Pleurotus eryngii species-complex isolates from Iran, and notes on the systematics of Asiatic populations. Mycol Progress 9: 181-194. DOI: 10.1007/ s11557-009-0624-2

Rohlf FJ. 2000. NTSYS-pc: Numerical taxonomy and multivariate analysis system, version 2.1. Applied Biostatistics, New York.

Sharon A. 2010. Molecular and Cell Biology Methods for Fungi. Department of Plant Sciences. Humana Press, New York.

Tsegaye Z, Tefera G. 2018. Cultivation of oyster mushroom (Pleurotus ostreatus Kumm, 1871) using agro-industrial residues. J Appl Microb Res 1: 1-6.

Vieira FR, Pereira DM, Nogueira de Andrade MC, Minhoni MT. 2013. Molecular characterization of Pleurotus ostreatus commercial strains by random amplified polymorphic DNA (RAPD). Afr J Agric Res 8: 3146-3150.

Windarsih G, Utami DW, Yuriyah S. 2019. Genetic diversity and productivity of Gracilaria coronopifolia as alternative for food resource based on RAPD marker. Biodiversitas 20: 3758-3765. DOI: $10.13057 /$ biodiv/d201239

Zhao M, Huang C, Chen Q, Wu X, Qu J. 2013. Genetic variability and population structure of the mushroom Pleurotus eryngii var. tuoliensis. PLoS One 8: e83253. DOI: 10.1371/journal.pone.0083253

Zhao M, Huang C, Wu X, Chen H, Qu J, Li Y, Gao W, Zhang J. 2016. Genetic variation and population structure of the mushroom Pleurotus ferulae in China inferred from nuclear DNA analysis. J Integr Agr 15: 2237-2246. DOI: 10.1016/S2095-3119(16)61383-7

Yadav MK, Chandra R, Singh HB, Yadav SK, Yadav SK, Naik S, Dhakad PK. 2017. Genetic diversity characterization of Pleurotus strains by random amplified polymorphic DNA fingerprinting. Intl J Curr Microbiol App Sci 6: 1260-1267. DOI: 10.20546/ ijcmas.2017.605.136. 